\title{
Oocyte quality of tambaqui (Colossoma macropomum) during the reproductive season
}

\author{
Galo, JM. ${ }^{a *}$, Ribeiro, RP. ${ }^{b}$, Streit-Junior, DP. ${ }^{c}$, Albuquerque, DM. , \\ Fornari, DC. ${ }^{d}$, Roma, CFC. ${ }^{e}$ and Guerreiro, LRJ. ${ }^{c}$ \\ anstituto Federal de Educação, Ciências e Tecnologia de Rondônia - IFRO, Câmpus Ariquemes, \\ Rodovia RO-01, km13, CEP 76872-862, Ariquemes, RO, Brazil

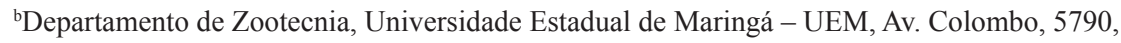 \\ CEP 87030-121, Zona 07, Maringá, PR, Brazil \\ 'Departamento de Zootecnia, Universidade Federal do Rio Grande do Sul - UFRGS, \\ Av. Bento Gonçalves, 7712, CEP 91540-000, Porto Alegre, RS, Brazil \\ ${ }^{\mathrm{d}}$ Genetic Fish Rise, Rodovia BR 163, km 713, Sala 02. s/no, CEP 78890-000, \\ Distrito de Primavera do Norte. Sorriso, MT, Brazil

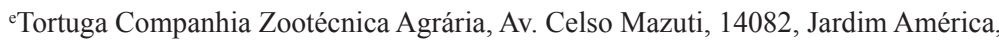 \\ CEP 78995-000, Vilhena, RO, Brazil \\ *e-mail: juliana.galo@ifro.edu.br
}

Received: June 11, 2013 - Accepted: March 12, 2014 - Distributed: May 31, 2015 (With 2 Figures)

\begin{abstract}
The study aimed to analyze the Colossoma macropomum reproductive behavior and quality of the female gametes throughout the reproductive season. The experiment was carried out in Pimenta Bueno - Rondônia State (Northern Brazil) during the reproductive season (2010-2011) using 36 females. Each sampling was performed on a $15 \pm 5$ days interval. Female gametes were collected by stripping and the following analyses were performed: weight of oocytes released (g); productivity index, fertilization and hatching rate. During the sampling period was verified effect $(\mathrm{p}<0.05)$ of collecting time into the season for oocytes weight, productivity index and fertilization rate. Although the period 3 (December) did not differ significantly from other periods, it showed better parameters for the quality of C. macropomum oocytes.

Keywords: Characidae, fertilization rate, oocytes, reproduction, reproductive period.

\section{Qualidade ovocitária de tambaqui (Colossoma macropomum) ao longo da estação reprodutiva}

\section{Resumo}

O estudo foi conduzido com o objetivo de analisar o comportamento reprodutivo da espécie Colossoma macropomum, quanto à qualidade de seus gametas femininos ao longo da estação reprodutiva. $\mathrm{O}$ experimento foi executado em Pimenta Bueno-Rondônia durante a estação reprodutiva do C. macropomum. Utilizaram 36 fêmeas durante a estação de 2010-2011. Cada coleta apresentou um intervalo de $15 \pm 5$ dias. Através da extrusão foram coletados os gametas femininos e realizadas as seguintes análises ao longo da estação: peso de oócitos liberados (g); índice de produtividade; taxa de fertilização e eclosão. Durante a estação 2010-2011 foi verificado efeito $(\mathrm{p}<0,05)$ de período (coleta) dentro da estação para peso de oócitos, índice de produtividade e taxa de fertilização. Apesar do período 3 (coleta - mês de dezembro) não ter diferenciado significativamente de alguns períodos, foi o que apresentou os melhores parâmetros estabelecidos para a qualidade dos oócitos de C. macropomum.

Palavras-chave: Characidae, taxa de fertilização, oócitos, reprodução, período reprodutivo.

\section{Introduction}

From the South American fish species farmed in Brazil Colossoma macropomum is characterized as one of the most important, due to its excellent zootechnical characteristics appropriate for farming, and also due to its great acceptance by the Brazilian consumer market (Urbinati and Gonçalves, 2005). It is an important professional and amateur fishing species, with great potential in farming fields and there is several scientific information available in literature. C. macropomum became the major species for cultivation in North and Mid-West of Brazil, being farmed in 24 of the 27 Brazilian states (Lopera-Barrero et al., 2011). 
Using high quality gametes is extremely important to ensure production of viable descendents for aquaculture (Bromage and Roberts, 1995). The quality of oocytes and production of larvae in captivity are considered very important and limiting factor in fingerlings production (Kjørsvik et al., 1990).

Oocyte quality is closely related to future larvae potential (Kjørsvik et al., 1990) and depends on several factors that can often change during the reproductive cycle. Aspects such as the female endocrine status during oogenesis, quantity and quality of feed during the preparation time, physical and chemical water parameters, stress by handling and others are listed as determinants for success in production of viable larvae (Campbell et al., 1992; Bromage, 1995; Brooks et al., 1997; Christiansen and Torrissen, 1997; Carrillo et al., 2000).

Chambers and Waiwood (1996) studying Gadus mohua, reported that the oocytes size reduced during the reproductive season due to the low supply in diet and subsequent maternal sub- nutrition. In reproductive season, oocytes achieve a critical size specific for the species (Romagosa et al., 1988), and larvae size after yolk sac absorption is correlated to the oocytes size.

Studies on fertility are important for fishing research (Almatar and Bailey, 1989). Information regarding eggs number is used to estimate reproductive potential and correlate fish length to fecundity (Laine and Rajasilta, 1998). Differences observed in fish fecundity are assigned to genetic and environmental factors (Baxter, 1959; Burd and Howlett, 1974; Messieh, 1976; Kelly and Stevenson, 1985; Sinclair and Trembley, 1984). Bromage (1995) suggests that female nutritional management influences the production of viable larvae. Furthermore, several authors report that the food level for females affects oocytes numbers (Watanabe, 1985; Horwood et al., 1989; Kamler, 1992; Tyler and Sumpter, 1996) and also variations in egg size (Hettler, 1981; Hay et al., 1988). Winters et al. (1993) reported from the physical environment, the sea water temperature influences the size and average number of eggs produced by fish.

There is no information available regarding the oocytes quality parameters and larvae of native Brazilian fish in captivity and subsequent fertilization and hatching rates. This information becomes important to successful of fish commercial production with constant supply of high quality oocytes.

This study aimed to analyze the breeding behavior of C. macropomum, assessing the quality of oocytes during the reproductive season in order to determine the best time to perform reproduction in captivity.

\section{Material and Methods}

The project was carried out in a commercial fish farm located in Pimenta Bueno, Rondônia, Northern Brazil (11 $41^{\prime} 460,95$ 'S and $61^{\circ} 13^{\prime} 47.50$ ' W) by the
Research Groups: PeixeGen - Maringa State University (UEM) and Aquam - Federal University of Rio Grande do Sul (UFRGS), during the C. macropomum breeding season, from early November 2010 until the end of March 2011 (150 days).

Data of air temperature and pluviometric index (precipitation) were collected from the meteorological station - CPTEC, in Cacoal city - Rondônia, located near the property which study was conducted. Were used 36 females $C$. macropomum $(9.3 \pm 2.5 \mathrm{~kg}$ and $6 \pm 2$ years), during the 2010-2011 season, which represented $40 \%$ of the breeding herd of the fish farming.

Animals were maintained in six nurseries of $2,000 \mathrm{~m}^{2}$, with an average water temperature of $28 \pm 2{ }^{\circ} \mathrm{C}$ and $6 \mathrm{mg} / \mathrm{L}$ of dissolved oxygen, fed with commercial feed $36 \%$ crude protein and 3,400 kcal DE / kg diet. They were fed three times a week with $1 \%$ of the biomass from August until the breeding season (October), when it was used the strategy of feeding twice a week with $1 \%$ of the biomass. After spawning, animals remained 15 days without food and returned to receive daily feeding with $3.5 \%$ biomass.

Animals were identified with transponders. Females were selected by secondary sexual characteristics in migratory fish, such as bulging and smooth abdomen, and reddish urogenital orifice. Afterwards, animals were weighed and submitted to intramuscular hormonal induction (extract of carp pituitary) between the dorsal fin and lateral line, being injected $5.5 \mathrm{mg} / \mathrm{kg}$ of body weight, applying $10 \%$ at the first administration and the remaining dosage 12 hours later.

Fish were maintained in two management tanks containing $3000 \mathrm{~L}$ (maximum of four animals in each one) with $70 \mathrm{~cm}$ water column, in constant flux under controlled temperature $\left(28 \pm 2{ }^{\circ} \mathrm{C}\right)$ and dissolved oxygen $(6 \mathrm{mg} / \mathrm{L})$.

The interval of each sampling was $15 \pm 5$ days. Being the period (1) - early November, (2) - end of November; (3) - mid December, (4) - early January; (5) - end of January; (6) - early February; (7) - end of February; (8) - early March and (9) - end of March.

Female gametes were collected by stripping (Woynarovich and Horváth, 1980) and the following analyzes were performed along breeding season:

Weight of released oocytes ( $\mathrm{g}$ ) - after each spawning, oocytes were weighed on analytical balance.

Productivity index - quantity of released oocytes (g) divided by animal weight, multiplied by 100 (IP = oocytes $(\mathrm{g}) /$ animal weight $(\mathrm{g}) * 100)$.

A $60 \mathrm{~mL}$ oocytes aliquot from each female was immediately fertilized with $150 \mu \mathrm{L}$ semen from one male in reproductive period. Afterwards, each aliquot was placed into $60 \mathrm{~L}$ incubators to complete the embryonic development. After six hours of incubation $\left(28^{\circ} \mathrm{C} \pm 1\right)$ it was determined the fertilization rate by counting 100 eggs 
from three aliquots of each incubator. Number of viable embryos and failed eggs was determined.

One hundred embryos were transferred to $3 \mathrm{~L}$ incubators, independently for each female. Twelve hours post fertilization $\left(28 \pm 1^{\circ} \mathrm{C}\right)$ was assessed the hatching rate. Number of hatched larvae and failed eggs was obtained by counting three aliquots of each incubator.

It was used the computer software Statistica ${ }^{\odot} 7.0$ to describe the database parameters: oocytes weight, productivity index, fertilization rate and hatching rate. It was also analyzed the assumptions of normality and homogeneity at $5 \%$ of waste by the Shapiro-Wilk and Levene test. Then submitted to ANOVA one way which evaluated the effect of reproductive period with $5 \%$ significance. In case of significant difference between at least one treatment, means were compared by Tukey test at $5 \%$. It was performed Pearson correlation index between the period and oocytes weight from C. macropomum females along the breeding season.

\section{Results}

Average air temperatures in 2010/2011 were: 26.2, 26.6, 26.2, 26.1 and $25.7{ }^{\circ} \mathrm{C}$ in November, December, January, February and March, respectively. Pluviometric indexes in 2010-2011 were 334.3, 229.6, 283.9, 459.1, and $365.4 \mathrm{~mm}$ in November, December, January, February and March, respectively (Figure 1).

It was checked effect ( $\mathrm{p}>0.05)$ for period (samplings) into the season for weight of oocytes released; productivity index and fertilization rate (Table 1). Although period 3 (sampling in December) did not differ significantly $(p>0.05)$ from other periods, it was the best one regarding oocytes quality.
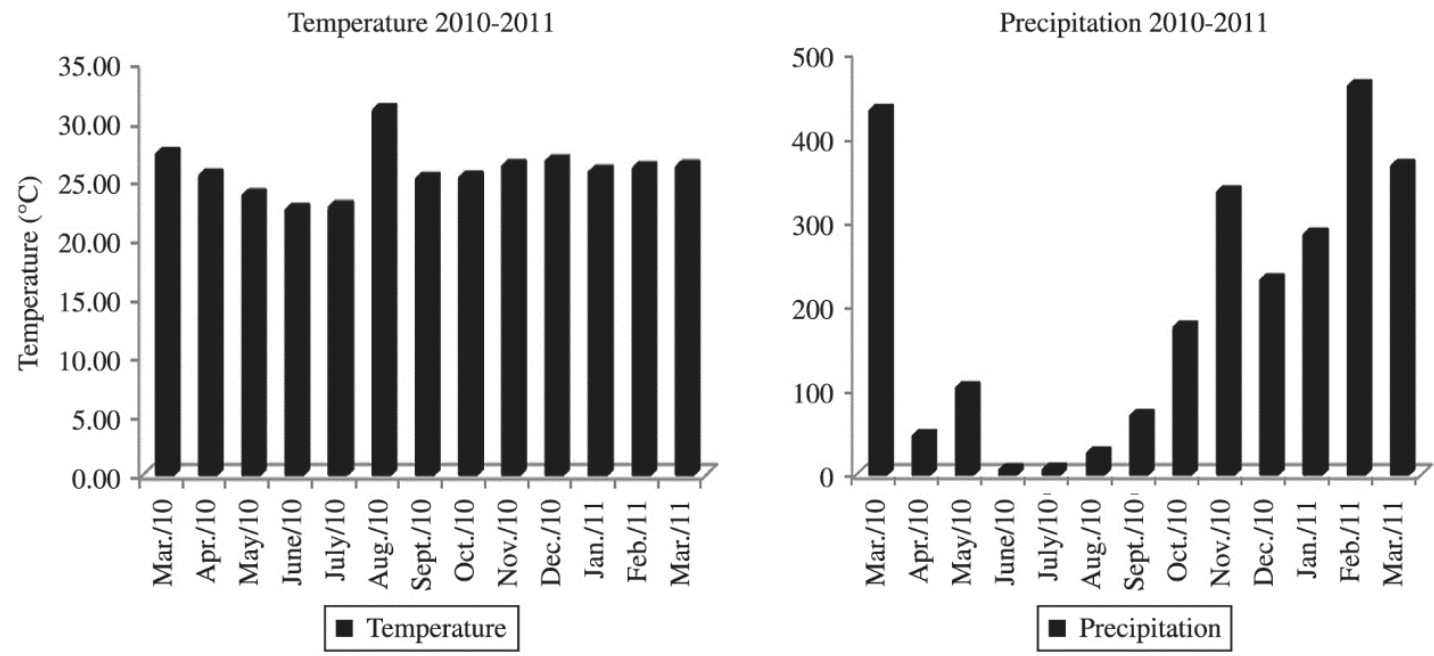

Figure 1. Monthly variation of average air temperature and precipitation in Pimenta Bueno city - Rondônia from March 2010 to March 2011 (AGRITEMPO, 2010)

Table 1. Qualitative parameters of Colossoma macropomum oocytes during the breeding season 2010/2011.

\begin{tabular}{ccccc}
\hline \multirow{2}{*}{$\begin{array}{c}\text { Reproductive period } \\
\text { (samplings) }\end{array}$} & Oocytes weight $(\mathbf{g})$ & $\begin{array}{c}\text { Quduction index } \\
\text { (PI) }\end{array}$ & $\begin{array}{c}\text { Fertilization rate } \\
\mathbf{( \% )}\end{array}$ & Hatching rate (\%) \\
\hline 1 & $1101.8 \pm 124.4 \mathrm{ab}$ & $10.38 \pm 1.41 \mathrm{abc}$ & $67.44 \pm 1.47 \mathrm{abc}$ & $67.12 \pm 14.25 \mathrm{a}$ \\
2 & $1070.0 \pm 204.9 \mathrm{ab}$ & $13.62 \pm 1.19 \mathrm{ab}$ & $86.30 \pm 3.41 \mathrm{a}$ & $68.57 \pm 17.57 \mathrm{a}$ \\
3 & $1830.0 \pm 159.0 \mathrm{a}$ & $16.90 \pm 0.33 \mathrm{a}$ & $85.75 \pm 9.95 \mathrm{ab}$ & $89.05 \pm 4.65 \mathrm{a}$ \\
4 & $778.00 \pm 149.8 \mathrm{~b}$ & $10.34 \pm 1.89 \mathrm{abc}$ & $73.06 \pm 12.60 \mathrm{abc}$ & $76.04 \pm 12.76 \mathrm{a}$ \\
5 & $852.0 \pm 225.0 \mathrm{ab}$ & $10.02 \pm 2.65 \mathrm{abc}$ & $69.00 \pm 23.60 \mathrm{abc}$ & $71.00 \pm 21.00 \mathrm{ab}$ \\
6 & $981.0 \pm 276.2 \mathrm{ab}$ & $13.51 \pm 0.85 \mathrm{ab}$ & $23.25 \pm 23.25 \mathrm{bc}$ & $22.95 \pm 22.95 \mathrm{bc}$ \\
7 & $1113.3 \pm 246.7 \mathrm{ab}$ & $10.01 \pm 2.71 \mathrm{abc}$ & $64.85 \pm 8.12 \mathrm{abc}$ & $54.09 \pm 19.54 \mathrm{ab}$ \\
8 & $894.7 \pm 89.8 \mathrm{ab}$ & $8.19 \pm 1.94 \mathrm{bc}$ & $8.00 \pm 6.11 \mathrm{c}$ & $0.00 \pm 0.00 \mathrm{c}$ \\
9 & $519.7 \pm 51.9 \mathrm{~b}$ & $4.98 \pm 0.49 \mathrm{c}$ & $70.32 \pm 8.49 \mathrm{ab}$ & $63.93 \pm 13.15 \mathrm{a}$ \\
$(\mathrm{F} ; \mathrm{p})$ & $3.7967 ; 0.0042$ & $0.36127 ; 0.9318$ & $4.0668 ; 0.002778$ & $2.13490 ; 0.0673$ \\
\hline
\end{tabular}

$\mathrm{PI}=$ oocytes $(\mathrm{g}) /$ body weight $(\mathrm{g}) * 100$. 
Period vs. weight ( $\mathrm{g}$ ) vs. weight of oocytes ( $\mathrm{g}$ ) Correlation: $\mathrm{r}=0.04842$ (Period $\mathrm{x}$ weight of females) $r=-0.4638$ (Period $x$ weight of oocytes)

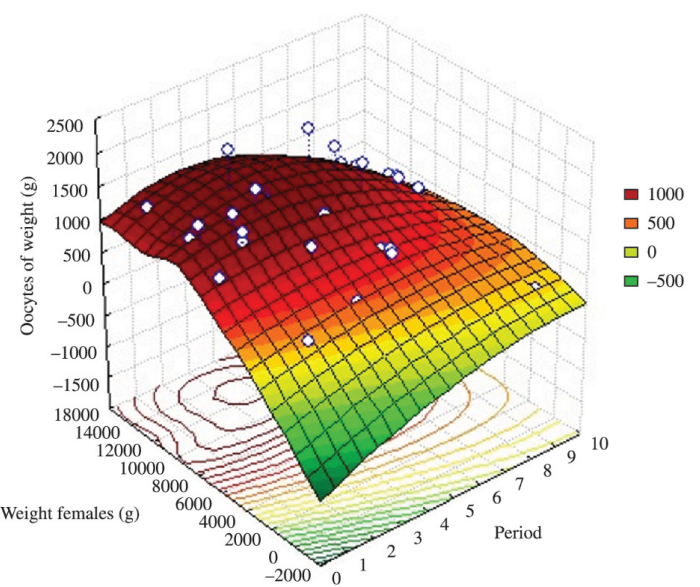

Figure 2. Correlations between the reproductive period, female weight $(\mathrm{g})$ and weight of released oocytes $(\mathrm{g})$.

According to correlations carried out between the reproductive period (samplings) and female weight $(\mathrm{r}=0.0484)$, and between reproductive period (samplings) and weight of released oocytes $(\mathrm{r}=-0.4638)$, it was observed females that had greater weight, and higher oocytes weight occurring in the first periods of sampling in November, December and January (Figure 2).

\section{Discussion}

According to Bobe and Labbe (2010) the oocytes quality in fish can be defined as the ability to be fertilized and consequently develop a normal embryo. In wild conditions or even in captivity, the quality of fish gametes can be highly variable and significantly influenced by several external factors beyond management of breeding and reproductive period (Chambers and Waiwood, 1996), such as environmental factors (Kraus et al., 2000), temperature (Tveiten et al., 2001), the feed level of females (Tyler and Sumpter, 1996) and sex relation of breeders (Pavlidis et al., 2004).

Macchi et al. (2004) studied oocyte production during the reproductive season of Merluccius hubbsiake and reported that the monthly production of oocytes varied considerably during the season, with a main peak in January ( $57 \%$ of oocytes produced during the period). In addition, older females ( $>5$ years) had production in longer period than younger ones. In the present study the female C. macropomum spawned from November to March, with a peak of oocytes weight in December. Furthermore, from the correlations between the female's weight, weight and reproductive period of oocytes it was possible to affirm that larger oocytes were released by heavier animals. This occurred in the early periods of sampling, indicating that older females were more precocious. According Signor et al. (2013) in studies with catfish (Rhamdia voulezi) observed that the major players have better reproductive capacity, keeping the proportion of eggs in relation to body weight.

Another observation by Macchi et al. (2004) with Merluccis hubbsi was that from December to February the number of oocytes produced per unit weight did not change. In March the oocytes production decreased considerably coinciding with increased gonads atresia. This fact was also observed for C. macropomum, where the productivity index (number of released oocytes /live weight) did not show differences between November and December, but presented significant difference between March, probably due to increased follicular atresia. The same authors reported that the fecundity of fish group studied was positively correlated with total length, total weight (without ovary) and age of $M$. hubbsi females, it's a range from 100,000 (32 cm total length) to 2.3 million (87 cm total length) of hydrated oocytes.

Related to age, the variation in chemical composition of fish oocytes were found in some studies, but did not seem to be a universal phenomenon. In contrast, the oocyte size can be predicted from the female age. During the breeding season the size of the oocyte may vary between successive batches. The positive relationships between female size and oocyte size with the size of fingerlings and resistance to starvation and predation is a fundamental way to parent-egg-progeny (Kamler, 2005).

The fertilization rate and hatching rate did not differ in the first period of November, December and January, but from February there was a decrease in these rates. The same behavior was observed by Barbieri et al. (2000) with wild Salminus maxillosus, reporting the spawning period from November to February. This fact was also observed in this study, as the small variation between the fertilization rates and hatching rates can be explained by abiotic factors such as rainfall.

According to Lowe-McConnell (1975), teleosts of tropical and subtropical regions own a close relationship between the reproductive period and the rainy seasons. For Munro (1990), there is evidence that temperature can be used as a source of information about the advent of appropriate conditions for spawning.

Temperature is an important factor to the reproductive processes in fish occurs regularly. In the overlapping temperature chart study period during the year, two situations bear watching, firstly, in August, when the fish were still under a latency period of embryonic development and second, since reproductive period the average temperature remained stable, with a slight decline in November (2010) to March 2011. Although this appears to be a little variation in temperature it may have been a factor that potentiated stress, after the systematic trawls to capture the animals in storage ponds.

The importance of temperature and photoperiod on reproduction is amply demonstrated in many species of fish (Munro, 1990; Bromage et al., 2001). Papadaki et al. (2008) studied the gametes quality of Diplodus puntazzo, and observed occurrence of spawning between the temperatures 19 to $21^{\circ} \mathrm{C}$, with an optimum temperature 
of $21^{\circ} \mathrm{C}$. When the temperature began to drop, spawning has also suffered a decrease.

Even in captivity, many species of fish have reproductive behavior similar to nature, abiotic factors such as water temperature and pluviometric rates significantly influence the changes in production of gametes during the reproductive season. According to Winters et al. (1993), from physical environments, seawater temperature influences the average number and size of oocytes produced in fishe. Longer Querol et al. (2002) studied L. platymetopon and Melo and Querol (1995) with L. anus observed in general, conditions for increasing temperature are linked to the period of greatest reproductive activity, directly affecting gonadal maturation.

Deeper researches in this area and assessment of qualitative and quantitative parameters of C. macropomum oocytes in new breeding seasons are required. In addition, observations of new parameters such as oocyte size, amount of fatty acids in the oocytes, number of oocytes/g would help to explain the interaction between the biotic/ environmental parameters and oocytes quality. Optimum results were observed during the periods of November, December and January, indicating it as the best time to perform the reproduction of the species.

\section{Acknowledgements}

The authors are grateful to Boa Esperança Fish Farm (Pimenta Bueno, Rondônia) for providing the facilities to this study, to the staff of PEIXEGEN and AQUAM research groups and the Aquabrasil Project (Embrapa) for the partnership in this work.

\section{References}

ALMATAR, SM. and BAILEY, RS., 1989. Variation in the fecundity and egg weight of herring Clupea harengus L.: part I. Studies in the Firth of Clyde and northern North Sea. Journal du Conseil Internation pour I'Exploration de la Mer, vol. 45, no. 2, p. 113-124. http://dx.doi.org/10.1093/icesjms/45.2.113.

BARBIERI, G., SALLES, FA. and CESTAROLLI, MA., 2000. Influência dos fatores abióticos na reprodução do dourado, Salminus maxillosus e do curimbatá Prochilodus lineatus do Rio Mogi Guaçu (Cachoeira de Emas, Pirassununga/SP). Acta Limnologica Brasiliensia, vol. 12, p. 85-91.

BAXTER, IG., 1959. Fecundities of winter-spring and summerautumn herring spawners. Journal du Conseil Internation pour I'Exploration de la Mer, vol. 25, no. 1, p. 73-80. http://dx.doi. org/10.1093/icesjms/25.1.73.

BOBE, J. and LABBÉ, C., 2010. Egg and sperm quality in fish. General and Comparative Endocrinology, vol. 165, no. 3, p. 535-548. http://dx.doi.org/10.1016/j.ygcen.2009.02.011. PMid:19272390

BROMAGE, N., PORTER, M. and RANDALL, C., 2001. The environmental regulation of maturation in farmed finfish with special reference to the role of potoperiod and melatonin. Aquaculture, vol. 197, no. 1-4, p. 63-98. http://dx.doi.org/10.1016/ S0044-8486(01)00583-X.
BROMAGE, NR. and ROBERTS, RJ., 1995. Broodstock Management and Egg and Larval Quality. Oxford: Blackwell Science.

BROMAGE, NR., 1995. Broodstock management and seed quality general considerations. In BROMAGE, NR. and ROBERTS, RJ. (Eds.). Broodstock management and egg and larval quality. Oxford: Blackwell Science. p. 1-24.

BROOKS, S., TYLER, CR. and SUMPTER, JP., 1997. Egg quality in fish: what makes a good egg? Reviews in Fish Biology and Fisheries, vol. 7, no. 4, p. 387-416. http://dx.doi. org/10.1023/A:1018400130692.

BURD, AC. and HOWLETT, GJ., 1974. Fecundity studies on North Sea herring. Journal du Conseil Internation pour I'Exploration de la Mer, vol. 35, no. 2, p. 107-120. http://dx.doi.org/10.1093/ icesjms/35.2.107.

CAMPBELL, PM., POTTINGER, TG. and SUMPTER, JP., 1992. Stress reduces the quality of gametes produced by rainbow trout. Biology of Reproduction, vol. 47, no. 6, p. 1140-1150. http://dx.doi. org/10.1095/biolreprod47.6.1140. PMid:1493180

CARRILLO, M., ZANUY, S., OYEN, F., CERDA, J., NAVAS, JM. and RAMOS, J., 2000. Some criteria of the quality of the progeny as indicators of physiological broodstock fitness. In BASURCO, B. Mediterranean aquaculture finfish species diversification. Zaragoza: CIHEAM. p. 61-74. Cahiers Options Mediterranées, no.47.

CHAMBERS, RC. and WAIWOOD, KG., 1996. Maternal and seasonal differences in egg sizes and spawning characteristics of captive Atlantic cod, Gadus morhua. Canadian Journal of Fisheries and Aquatic Sciences, vol. 53, no. 9, p. 1986-2003. http://dx.doi.org/10.1139/cjfas-53-9-1986.

CHRISTIANSEN, R. and TORRISSEN, OJ., 1997. Effects of dietary astaxanthin supplementation on fertilization and egg survival in Atlantic salmon (Salmo salar L.). Aquaculture, vol. 153, no. 1-2, p. 51-62. http://dx.doi.org/10.1016/S0044-8486(97)00016-1.

HAY, DE., BRETT, JR., BILINSKI, E., SMITH, DT., DONALDSON, EM., HUNTER, GA. and SOLMIE, AV., 1988. Experimental impoundments of prespawning Pacific herring Clupea harengus pallasi.: effects of feeding and density on maturation, growth, and proximate analysis. Canadian Journal of Fisheries and Aquatic Sciences, vol. 45, no. 3, p. 388-398. http://dx.doi.org/10.1139/ f88-047.

HETTLER, W., 1981. Spawning and rearing Atlantic menhaden. Progressive Fish-Culturist, vol. 43, no. 2, p. 80-84. http://dx.doi. org/10.1577/1548-8659(1981)43[80:SARAM]2.0.CO;2.

HORWOOD, JW., WALKER, MG. and WITTHAMES, P., 1989. The effect of feeding levels on the fecundity of plaice Pleuronectes platessa. Journal of Marine Biological Association of the United Kingdom, vol. 69, no. 01, p. 81-92. http://dx.doi.org/10.1017/ S0025315400049122.

KAMLER, E., 1992. Early life history of fish. London: Chapman \& Hall. Chapman and Hall Fish and Fisheries Series.

KAMLER, E., 2005. Parent-egg-progeny relationships in teleost fishes: an energetic perspective. Reviews in Fish Biology and Fisheries, vol. 15, no. 4, p. 399-421. http://dx.doi.org/10.1007/ s11160-006-0002-y.

KELLY, KH. and STEVENSON, DK., 1985. Fecundity of Atlantic herring Clupea harengus from three spawning areas in the northern Gulf of Maine, 1969 and 1982. Journal of Northwest Atlantic Fishery Science, vol. 6, no. 2, p. 149-155. http://dx.doi. org/10.2960/J.v6.a15. 
KJØRSVIK, E., MANGOR-JENSEN, A. and HOLMEFJORD, I., 1990. Egg quality in fishes. Advances in Marine Biology, vol. 26, p. 71-113. http://dx.doi.org/10.1016/S0065-2881(08)60199-6.

KRAUS, G., MÜLLER, A., TRELLA, K. and KÖSTER, FW., 2000. Fecundity of Baltic cod:temporal and spatial variation. Journal of Fish Biology, vol. 56, no. 6, p. 1327-1341. http:// dx.doi.org/10.1111/j.1095-8649.2000.tb02146.x.

LAINE, P. and RAJASILTA, M., 1998. Changes in the reproductive properties of Baltic herring females during the spawning season. Fisheries Research, vol. 36, no. 1, p. 67-73. http://dx.doi. org/10.1016/S0165-7836(98)00087-3.

LOPERA-BARRERO, NM., RIBEIRO, RP. and POVH, JA., 2011. Produção de organismos aquáticos: uma visão no Brasil e no mundo. Guaíba: Agrolivros. 320 p.

LOWE-MCCONNEL, RH., 1975. Fish communities in tropical freshwater. London: Longman.

MACCHI, GJ., PÁJARO, M. and EHRLICH, M., 2004. Seasonal egg production pattern of the Patagonian stock of Argentine hake (Merluccius hubbsi). Fisheries Research, vol. 67, no. 1, p. 25-38. http://dx.doi.org/10.1016/j.fishres.2003.08.006.

MELO, JF. and QUEROL, MV., 1995. Dados preliminares sobre biologia e reproduçao de cascudo viola Loricariichthys anus (Pisces, Liricariidae) na região Uruguaiana, RS, Brasil. Hifen, vol. 19, p. 34-37.

MESSIEH, SN., 1976. Fecundity studies on Atlantic herring from the southern Gulf of St. Lawrence and along the Nova Scotia Coast. Transactions of the American Fisheries Society, vol. 105, no. 3, p. 384-394. http://dx.doi.org/10.1577/1548-8659(1976)105<384:FS $\mathrm{OAHF}>2.0 . \mathrm{CO} ; 2$

MUNRO, AD., 1990. Tropical freshwater fish. In MUNRO, AD.; SCOTT, AP. and LAM, TJ. Reproductive seasonality in teleosts:environmental influences. Boca Raton: CRC Press. p.145-239.

PAPADAKI, M., PAPADOPOULOU, M., SIGGELAKI, I. and MYLONAS, CC., 2008. Egg and sperm production and quality of sharpsnout sea bream (Diplodus puntazzo) in captivity. Aquaculture, vol. 276, no. 1-4, p. 187-197. http://dx.doi.org/10.1016/j. aquaculture.2008.01.033

PAVLIDIS, M., GREENWOOD, L. and SCOTT, AP., 2004. The role of sex ratio on spawning performance and on the free and conjugated sex steroids released into the water by common dentex (Dentex dentex) broodstock. General and Comparative Endocrinology, vol. 138, no. 3, p. 255-262. http://dx.doi. org/10.1016/j.ygcen.2004.06.004. PMid: 15364208

QUEROL, MVM., QUEROL, E. and GOMES, NNA., 2002. Fator de condição Gonadal, índice Hepatossomático e Recrutamento como Indicadores do período de reproduçao de Loricariichthys platymetopon (Osteichthyes, Loricariidae) Bacia do Rio Uruguai Médio, Sul do Brasil. Iheringia. Série Zoologia, vol. 92, no. 3, p. 79-84. http://dx.doi.org/10.1590/S0073-47212002000300008.

ROMAgOSA, E., PAIVA, P. and GODINHO, HM., 1988. Desenvolvimento dos ovócitos de Piaractus mesopotamicus (Holmberg, 1987) (=Colossoma mitrei Berg, 1985) em condições de cultivo intensivo. Ciencia e Cultura, vol. 63, p. 60-64.

SIGNOR, A., FEIDEN, A., BOSCOLO, WR., SIGNOR, AA., GONÇALVES, GS., SARY, C. and KLEIN, S., 2013. Eventos reprodutivos do jundiá Rhamdia voulezi cultivado em tanquesrede. Revista Brasileira de Reprodução Animal., vol. 37, no. 3, p. $272-277,</ \mathrm{jrn}>$.

SINCLAIR, M. and TREMBLEY, MJ., 1984. Timing of spawning of Atlantic herring Clupea harengus harengus, populations and the match-mismatch theory. Canadian Journal of Fisheries and Aquatic Sciences, vol. 41, no. 7, p. 1055-1065. http://dx.doi. org/10.1139/f84-123.

Sistema de Monitoramento Agrometeorológico - AGRITEMPO, 2010. Estatísticas: Cacoal - 31993 /SEDAM: 01/01/78 - 02/05/15. Embrapa Informática Agropecuária/ Cepagri Meteorologia Unicamp. Available from: <http:// http://www.agritempo.gov.br/agritempo/ jsp/Estatisticas/index.jsp?siglaUF=RO $>$. Access in: 29 Apr. 2015.

TVEITEN, H., SOLEVAG, S. and JOHNSEN, H., 2001. Holding temperature during the breeding season influences final maturation and egg quality in common wolffish. Journal of Fish Biology, vol. 58, no. 2, p. 374-385. http://dx.doi.org/10.1111/j.1095-8649.2001. tb02259.x.

TYLER, CR. and SUMPTER, JP., 1996. Oocyte growth and development in teleosts. Reviews in Fish Biology and Fisheries, vol. 6, no. 3, p. 287-318. http://dx.doi.org/10.1007/BF00122584.

URBINATI, EC. and GONÇALVES, FD., 2005. Pacu (Piaractus mesopotamicus). In BALDISSEROTO, B. and GOMES, LC. (Eds.). Espécies nativas para a piscicultura no Brasil. Santa Maria: UFSM. p. 225-246.

WATANABE, T., 1985. Importance of the study of broodstock nutrition for further development of aquaculture. In COWEY, CB., MACKIE, AM. and BELL, JG. (Eds.). Nutrition and Feeding in Fish. London: Academic Press. p. 395-414.

WINTERS, GH., WHEELER, JP. and STANSBURY, D., 1993. Variability in the reproductive output of spring-spawning herring in the northwest Atlantic. ICES Journal of Marine Science, vol. 50, no. 1, p. 15-25. http://dx.doi.org/10.1006/jmsc.1993.1003.

WOYNAROVICH, E. and HORVÁTH, L., 1980. The artificial propagation of warm-water finfishe: a manual for extension. Rome: FAO. 